ISSN 2179-345X

\title{
The law of the land: intangible and tangible rights in Aboriginal Australia
}

\author{
A lei da terra: direitos intangíveis e tangíveis \\ na Austrália aborígine
}

\begin{abstract}
Ana Elisa Monteiro Penteado
Ph.D. in Philosophy and Law at Macquarie University, Sydney-Austrália. Master in Law at University of California at Berkeley, Boalt Hall School of Law, Berkeley-USA.

e-mail: penteado.ana2008@googlemail.com
\end{abstract}

\section{Abstract}

This article deals with the Convention on Biological Diversity, article $8(j)$ in connection to the national and local legislation to be enacted prior to article 8 (j) enforcement. It shows that for legal protection of Indigenous Peoples's intangible rights, land rights are to be resolved by government and organisms devoted to land right claimed by Aboriginal Peoples. The experience of Australia through its recent colonization, decolonization and review of social values presented by Rudd Administration secured Indigenous Peoples rights. 
In conclusion, this article proposes a multi-action from historical, political, legal and jurisprudential sources for article 8 (j) to be operative.

Keywords: Terra nullius. CBD. Article 8 (j). Aboriginal rights. Land rights.

\section{Resumo}

Este artigo trata dos direitos intangíveis dos povos indígenas, na Convenção de Diversidade Biológica, artigo 8 (j), propondo que a proteção local deve ser antecipada pelo Estado, o qual deverá resolver os direitos de terra. Para tanto, os organismos de governo deverão ser exclusivamente dedicados à solução do direito indígena no tocante a reivindicações de terra. Ilustra-se a experiência da Austrália, através do seu período de colonização, descolonização e da recente mudança democrática, que representou uma revisão no passado histórico, político, sociolegal e jurisprudencial.

Palavras-chave: Convenção biodiversidade. Artigo 8 (j). Povos indígenas. Colonização. Direito de propriedade.

\section{Introduction}

The Convention on Biological Diversity (1992) invested intangible rights for Indigenous Peoples. The celebrated article 8 ( $j$ ) in the Convention on Biological Diversity provides protection to Traditional Knowledge owners occupying a given traditional land. Named as gatekeepers of local biodiversity, Indigenous Peoples still struggle to secure their land rights locally, though. This paper explores mainly the argument of reasonable and expected connection between land rights enjoyment and Traditional Knowledge custodianship according to article 8 (j). It embraces the theory that without enjoying property, Indigenous Peoples are not empowered to protect their Traditional Knowledge. Therefore, if land rights are not proclaimed by national and local legislation, there is non-enforcement for article $8(\mathrm{j})$ by States that ratified 
the Convention. Among all Indigenous Peoples and States that ratified the Convention on Biological Diversity, this paper focuses on the Australia and Aborigines historical struggle to illustrate the land rights claims in connection to the Traditional Knowledge's legal protection. The Aboriginal culture in Australia had suffered consistent dilution and western assimilation that has been gradually curtailed after Mabo decision in 1992. The true reconciliation occurred not long ago with an emotional speech addressed to Aborigines by recent administration of Kevin Rudd (2007-2010). In this paper, some selected works in Australian historical, social and legal materials are combined in an effort to demonstrate that land rights are associated with intangible rights, that is to say, Traditional Knowledge survived through the determination of land rights claims presented to the National Native Title Tribunal, which are subject to be determined by the Federal Court of Australia. At international level, The Convention on Biological Diversity offers guidance to national and local land rights legislation, which in the case of Australia an historical, political and legal change of attitude has occurred prior to the ratification of the Convention. Australia is a good example that domestic legislation ought to be enforceable locally to determine land rights claims in order to effectively enforce intangible rights protection proposed at the international level.

\section{Background of the political issues involving the Convention}

The concept of biodiversity conservation is supported by the Convention on Biological Diversity encapsulated on article 8 (j). In short, article 8 (j) declares that conservation maintains Traditional Knowledge, innovations and practices perpetuated by Indigenous Peoples, but national legislation should be enacted to delimit rights and obligations. The Convention's aims are positive but rather declaratory and diplomatic leaving States to choose the level of legal protection at discretion. Nonetheless, to embrace article 8 (j) in local legislation is much more 
complex than intangible rights protection recognition to Indigenous People's practices, innovation and on-going tradition,

Article 8 (j), Traditional Knowledge is: "knowledge, innovations and practices of indigenous and local communities, around the world. Developed from experience gained over the centuries, and adapted to the local culture and environment, traditional knowledge is transmitted orally from generation to generation. It tends to be collectively, owned and takes form of stories, songs, folklore, proverbs, cultural values, beliefs, rituals, community laws, local language, and agricultural practices, including the development of plant species and animal breeds. Traditional knowledge is mainly of a practical nature, particularly in such fields as agriculture, fisheries, health, horticulture, forestry and environmental management in general" (CONVENTION ON BIOLOGICAL DIVERSITY, 1992).

Lacking Aboriginal land rights determination threatens biodiversity preservation which in due time shall affect all indistinguishably. Land rights determination is crucial to maintain local custodians in control of their local knowledge, that is to say, to be biodiversity gatekeepers and owners in their own right. This paper presents Australian legislation and jurisprudential material that has examined the question of Aboriginal land rights as well as issues related to Aboriginal intangible rights before the Australian highest court. Another fact is that Australian society has been gradually evolving from indifference to social acceptance of Aboriginal ownership to traditional lands. Possibly it is due to the landmark decision for Aboriginal litigants Eddie Koiki Mabo, James Rice and David Passi against the State of Queensland confirmed by the High Court of Australia in 1992 (HIGH COURT OF AUSTRALIA, 1988). This legal test put forward to the High Court of Australia by Aboriginal claimants was to define common law before the land rights claims of the Torres Strait Islands to their traditional land. It is worth to note that the High Court of Australia had not being assisted by the Privy Council sitting in the United Kingdom, which meant more independence to create jurisprudence for the new democratic nation. This jurisprudential task was 
a challenge itself as the court had to illustrate the paradox of the black letter law shaped by the English power in opposition to the historical evidence of consistent failure in recognizing Aboriginal fundamental rights of property.

Due to the Australia Act 1986, any appeals to the Court of England were terminated as well as any legislative power over Australian jurisdiction, therefore all judgments from the High Court Australia after the Act was enacted were considered final. Prior to the Act of 1986, the Privy Council regarded Aboriginal Peoples from British colonies as "so low in the scale of social organization" therefore "idle to impute to [them] some shadow of the rights known to our law and then to transmute it into substance of transferable rights of property as we know them" (COMMONWEALTH, 1986, p. 1).

Luckily, the evolution of international law from assimilation policies tolerance to an human rights approach was supported by the High Court of Australia. Consequently, the court revisited historical evidence of Aboriginal dispossession making Mabo a landmark human rights decision and challenging absolute beneficial property title in international law. The Australian common law jurisprudence may possibly be asserted as one of the few legal theories for property protection where common law and civil law converge to similar interpretations. This is due to the theories that spoused colonization theories driven by race-driven policy.

It is necessary that either defined possession or interest by Indigenous Peoples must be prescribed by local law for courts to interpret clearly what the Indigenous Peoples's land rights are. If a sense of defeat is present, no political inclusiveness with a lack of information about land rights persist, no stand against future claims is the most likely result. Moreover, once land rights are assigned by local law to third parties, it is rather unlikely that their cultural manifestations will last. The bond with the land is what makes their survival as a nation possible. Nation is understood as a distinctive group of individuals or race not restricted to the old definition of sovereignty state, which gave reason for colonization 
policies among other things. Indigenous Peoples have a connection to the land that enhances their capacity to be considered as peoples as opposed to minorities (PENTEADO, 2008). That connection to the traditional land permits them to perpetuate their know-how of local biodiversity, that is to say, Traditional Knowledge with its innovations and practices. The failure to determine their land claims at the national and local level leads to a dispossessed community lacking moral determination to protecting their intangible rights.

\section{The Convention on Biodiversity article 8 (j): an update definition and its implementation locally}

The Convention on Biological Diversity, hereinafter CBD, was opened to signatures in June 1992 at the Earth Summit in Rio de Janeiro, coming into force in June 1993. It has been ratified by 193 parties, (Secretariat of the Convention on Biological Diversity, 2010, List of Parties) although in some States like Australia the act of incorporation (UNITED NATIONS, 1969, p. 2), into domestic law has been considered quite slow to give full effectiveness to the CBD. In Australia, the act of incorporation of treaties is the ultimate degree of enforcement of a multilateral treaty within local boundaries, in order for being considered enforceable at local level. If the international treaty is lacking implementation at local level by the legitimate authority or government, it is arguable whether international obligations are effectively implemented in the country erga omnes (REPORT, 2003). Until recently, 153 countries submitted their Fourth National Reports being due on last March 2009 but countries are still lodging it in the last month like Maldives (CONVENTION ON BIOLOGICAL DIVERSITY, 1992). The lodgement of national reports generated good will among all parties towards the treaty, nonetheless what is necessary is that the government must be also committed to share information to the public, (The Australian government, Dep. of Heritage and Arts) in order to involve citizens in the project of 
policies inclusion (Australia Council, IAACCC, scope of the code) the and finally to allocate economic resources for Indigenous Peoples's initiatives to be part of the local society (Australia Council, IAACCC, scope of the code) In Australia, the effective CBD in article 8 (j) started to have shape and implementation after Prime Minister Kevin Rudd took office in 2007.

The role of the Convention on Biodiversity, particularly article 8 (j), is setting guidelines for Traditional Knowledge holders as active stakeholders of biological conservation in-situ and sustainability of natural resources as well as encouraging "the equitable sharing of the benefits arising from the utilization of knowledge, innovators and practices" (Secretariat of the Convention on Biological Diversity, Convention on Biological Diversity, art. 8). Local policies that have failed systematically to enforce Indigenous Peoples's rights especially free access to their traditional lands send a message of distrust. Let alone to have an effectively veto power over the act of collecting natural resources insitu from traditional Indigenous lands by governments or companies authorized without Indigenous Peoples's formal consent, which is appalling (SPEECHES, 1995). Consequently, it is fair to say that survival of Traditional Knowledge and practices associated to natural resources are connected to the land rights determination due to an intangible possession of intuitive knowledge (chemical, religious, or food related) about that particular biodiversity since immemorial time (AUSTRALIAN GOVERNMENT, 1993, section 223). To think the opposite is to support assimilation theory, which would result in absent self-determination to first inhabitants. Let's make it clear - migration of westerners is global, migration of Indigenous Peoples is a form of exile. Following this logic, Indigenous Peoples forced to migrate to other regions in the planet unknown to them most likely may fail to mimic similar connection to the traditional land they have left. This is because their skills are designed to their local necessities and according to their own cultural beliefs. The unique local biodiversity that they once nurtured and learned to survive with would possibly be of no use in the new region they occupy. In other words, the connection to the new migrated land is inexistent. One could 
easily assume that cultural manifestations as Traditional Knowledge depend upon their traditional land occupation and consistent interaction with that unique geographical region.

The bizarre migratory hypothesis illustrates how important traditional land is for Indigenous Peoples as a cultural connection to the land they inhabit for time immemorial. It seems rather insensitive to even consider that Indigenous Peoples's land rights are not part of the equation to solve social problems of our past colonization times. If land rights are not important for Aborigines to connect to their culture, as some still apparently support (GURRY, 2006), it seems rather hypocritical to impose on them an obligation of natural resources custodians over a property right that can be dispossessed without any compensation or consultation of their opinion. It is clear that, to be implemented with full enforcement at local level, article $8(j)$ shall resort a priori to the condition sine qua non of Indigenous Peoples possessing an interest in the land or holding a native title on the land, so that as a result they are in control of their decision-making process.

In Australia, the native title for entitlement of land was construed by the Legislative power to provide a legal basis for land rights claims. But it was not an easy legal construction to sell out as international law incorporation demanded fair accountability to land claims in Australian European farmers mind. It is fair to say that Australian ratification to the Racial Discrimination Act back in 1975 gave legal support to Mabo v. Queensland [n.2] (1992) claims and to challenge the status quo, which resulted on the Native Title Act to be enacted afterwards. The Native Title Act of 1993 amended in 2006 basically secured the right for Aboriginal Peoples to negotiate, to be compensated fairly for use of Aboriginal land, including to actively managing Australian natural resources in cooperation with other non-Aboriginal stakeholders. Another aspect of the National Native Title Act concerns the legal structure and organization system in the government, that is to say, the Native Title Act of 1993 created a Tribunal dedicated solely to solve claims of land rights involving Aboriginal Peoples. Furthermore, the creation of a National 
Native Title Registry for registration of claims, allowed an archive of land claims and claimants for jurisprudence, being the registry branches situated all over the country.

The National Native Title Tribunal registry, Native Title in Australia available at nonetheless, there are procedures to be perfected as it is not a clear path to a fair negotiation process after the land claims are registered. Aboriginal and non-Aboriginal parties seem to have a work in progress to negotiate their contractual rights, with basic issues in communication of terms, understanding of language which is most of the times misunderstood between parties. Although the use of Indigenous Land Usage Agreements helped parties to manage issues of land rights in a form of an agreement, it lacked effectiveness when an economical project of long-term impact such as a mining agreement is drafted. It is common to observe that parties do not mean what they say especially in the commercial terms. In their experience with commercial contracts, Aboriginal parties have become increasingly skeptical of non-Aboriginal stakeholders dealings if a common protocol is not agreed between them. See, Richard Howitt, Towards Native Title Agreements: issues of negotiation or organization, paper presented at Aboriginal Issues in Resource Development, Native Title Unit, Aboriginal Legal Rights Movement of South Australia (AUSTRALIA..., 1993).

Australia has advanced extremely well in regard to the recognition of Aboriginal self-determination in the Rudd administration, which does not erase the efforts from the past. Before Prime Minister Rudd took office in 2007, land claims were progressing slowly (PARRY; JARVIS, 2003). Although each country has its own history and pace, some elements must be present to affect Indigenous People's rights to achieve fairness and justice. Elements like good will among stakeholders, recognition of Indigenous Peoples' inclusion in the society, self-respect, education and information about land rights and obligations at local and international level gave a chance to the social process to progress and to pacify stakeholders.

\section{Historical Background in Australia: before Mabo}




\section{and post Mabo, sleeping with the enemy}

The discussion of the Aboriginal rights regarding local natural resources in their traditional land has been examined to a great detail in Australian jurisprudence, legal treaties and historical accounts, for supporting the fact that Aborigines have being dispossessed from their country.

The Larrakia people have been dispossessed of their land but the Kembi Land Claim has re-estated their land rights. Langton observed on p. 45: "The Larrakia have arguably suffered greater dispossession of their land and lifestyle than Aboriginal people in some of the more remote areas of the Northern Territory. However, belated recognition of their rights through both the settlement in 2000 of the Kembi Land Claim on the Cox Peninsula (a claim lodged in 1979 under the Aboriginal Land Rights (Northern Territory) Act 1976 (CTH)) and opportunities conferred by the recognition of native-title rights at common law and the subsequent Native Title Act 1993 (Cth) (NTA), has provided increasing legal recognition of the Larrakia's traditional interest in land in the Darwin region. This increasing recognition has forced, for reasons of legal and political expedience, both the Northern Territory government and the private sector to proceed with negotiations and agreement making with the Larrakia" (LANGTON et al., 2004, p. 45).

This revisited issue involved reshaping what was Aboriginal right; and self-determination as a concept for which Australian society was reluctant to review for a long time. The process of Reconciliation, a social movement that gained momentum in the 1967 referendum by removing from the Australian constitution any racial discrimination towards Aboriginal Peoples, gave some support to Aboriginal governance and control towards their traditional knowledge usage (HOWITT, 1998) but never self-respect was consistently developed although so needed. Self-respect and the recognition of inclusiveness in the Australian society came in 2008, when elected Prime Minister Kevin Rudd offered a public and national apology to the Aboriginal Peoples in an emotional sorrow celebrated throughout the nation impressive even for foreigners as an 
attitude of positive reconciliation. Recently, Prime Minister Julia Gillard has announced a referendum for 2012 to eradicate the racial discrimination still present in the Australian Constitution, section 51 that still allows racial discriminatory laws.

Back to the Convention on Biological Diversity, although Australia has ratified it, including article $8(j)$, one should note that earlier legislation has dealt indirectly with preservation of Traditional Knowledge. For instance, the Aboriginal Lands Trust Act of 1966 and the Aboriginal Land Rights Act (Northern Territory) in 1976 are some of the local legislation dealing with Aboriginal land rights securing interests on traditional land. But action was not coordinated nationally and locally towards Indigenous land rights, therefore it resulted in diverse results within Australian states and discretion to local legislature to restrict rights and obligations.

In the history of recent colonization, it seems that the discovery of Australia by the Crown of England was an automatic render of Aboriginal sovereignty or an abrupt dispossession of the land by the English law, following the international law principle of res nullius theory. And nullius as people they were still after decolonization.

Unaware of their fate, Aboriginal Peoples have been occupying their traditional land and actively sharing their Traditional Knowledge ipso facto, in full assumption that territory in Australia was theirs. However, it was not until Eddie Koiki Mabo and others provoked the Queensland High Court with land rights question, which subsequently went to the High Court of Australia as Mabo v. Queensland [n.2] (1992) that a final decision was made on whether the Merriam people of the Murray Island in the Torres Strait were the traditional owners of their local land by right. The Aboriginal relationship with land and common law was then asserted by a new definition of property "common law native title".

Eddie Mabo and Others v. The State of Queensland [2], F.C. 92/014 High Court of Australia, Full Court. 1992175 CLR 1. Accordingly to Justice Brennan's opinion: "In rejecting the conclusion reached by 
the Supreme Court of Nigeria to the effect that native "title" under the earlier law or custom had been extinguished upon the establishment of the Colony by cession, ownership, the said: "That title... is prima facie based, not on such individual ownership as English law has made familiar, but on a communal usufructuary occupation... In [our] opinion there is no evidence that this kind of usufructuary title of the community was disturbed in law" [...] We shall, hereafter, use the phrase "common law native title" to refer generally to that special kind of title. The content of such a common law native title will, of course, vary according to the extent of the pre-existing interest of the relevant individual, group or community. It may be an entitlement of an individual, through his or her family, band or tribe, to a limited special use of land in a context where notions of property in land and distinctions between ownership, possession and use are all but unknown" (AUSTRALIA, 1992).

Mabo decision recognized that in common law it was possible to have non-extinguishment of native title, "in areas where Australia's indigenous people have maintained a traditional connection with land" (Mabo) Indeed, that was a change of course.

In Mabo, Justice Brennan proposed a declaratory decision to the full court to override earlier decisions in the context of international treaties ratified by Australia by stating that:

Our conclusion that rights under common law native title are true legal rights which are recognized and protected by the law would, we think, have the consequence that any legislative extinguishment of those rights would constitute an expropriation of property, to the benefit of the underlying estate [...]. And even more important restriction upon legislative powers to extinguish or diminish common law native title flows from the paramountcy of valid legislation of the Commonwealth Parliament over what would otherwise be valid State or Territory legislation. In particular, as Mabo v. Queensland has demonstrated the provisions of the Racial Discrimination Act 1975 (Cth) represent an important restraint upon State or Territory legislative power to extinguish or diminish common law native title (AUSTRALIA, 1992). 
Finally, it was established a landmark test for re-interpretation of Aboriginal land title, which gradually evolved to the enactment of Native Title Act 1993. The statutory rules of the Native Title Act 1993 (Cth) enacted procedures and new structures to deal with claims of land rights such as the National Native Title Tribunal. Thus national legislation introduced the legal mechanisms for negotiation among Aboriginal and non-Aboriginal parties in regard to land usage through a legal framework in a form of contractual basis called Indigenous Land Use Agreements, hereinafter ILUAs. Basically, it is an agreement between interested parties to use and manage an identified land and its waters in Australian territory. As of November $2^{\text {nd }}$ on 2010, the Native Title National Tribunal had 467 ILUAs agreed and.

Because Australia is an isolated continent, it was possible to control access to the Aboriginal communities by non-Aboriginal parties including foreigners interested in research and biological prospecting natural resources. Then one could make a point that Aboriginal Peoples were protected from non-Aboriginal Peoples. Nonetheless, it is not a surprise to know that policy-makers approved new interpretations to Aboriginal land in accordance to the economic principle rather than securing Aboriginal Peoples rights, as a Australian constitutional right (HOWITT, 2003).

\section{More historical res nullius evidence: the tale of Aboriginal property retold}

In 1987, Henry Reynolds's published a book entitled The Law of the Land which revisited white Australians and its English colonization from the perspective of Aboriginal Peoples's historical account. The evidence of unfairness and misjudgement towards Aboriginal Peoples were unmistakable, Reynolds's arguments addressed a re-interpretation of applied common law in Australian for dispossessed Aboriginal land rights. Was it true that Australia was acquired or discovered as a whole country 
"waste and unoccupied" or better saying a land "desert and uncultivated"? Reynolds questioned.

Reynolds researched substantial evidence for settlers to take possession of Australia, like he mentioned: "Despite all evidence to the contrary, the law continued to insist that Australia was unhabitated, that no one was in possession. Various jurists described the country as being "waste and unhabitated", "waste and unoccupied," "desert and unhabitated", "unpeopled"”. Reynolds noticed that: "some books published before 1788 and Crown Law Officers determined that New South Wales had been taken possession of as "desert and uninhabitable"; the South Australian Constitution Act (1834) referred to the land of the colony as being "waste and unoccupied", on p. 38. Further, Reynolds's analysis on ps. 41-42: "Given Blackstone's views on the colonisation of already inhabited lands and his comments on the rights acquired by original occupation, it is clear that it is only a very selective reading that he can be presented as the facto apologist for the expropriation of Aboriginal land. The British could only claim sovereignty over New South Wales, as well as proprietorship of every inch of landed property, if indeed it was unhabitated. [...] Many were like G. A. Robinson, who in 1832, confirmed that he was "at a loss to conceive by what tenure we hold this country" (REYNOLDS, 1987, p. 5).

Reynolds's persuasive logic and research illustrated how fallacious a legal theory in international law - res nullius theory - can be shaping some legitimacy on new colonies possession in common law. Moreover, res nullius theory was further used for creating a false status quo (of dispossession) based on legal-political circumstances of the moment (REYNOLDS, 1987, p. 4-42).

One of the key arguments for Aboriginal land rights and its dispossession is written in a compelling statement in official documents dated from around the Australian settlement by England on which it is stated: "There was nothing we could offer that they would take except provisions and those we wanted ourselves" (REYNOLDS, 1987, p. 64). It is quite obvious that the negotiation process did not succeed between 
Aborigines and Europeans. It is unclear as for how fair was then the negotiation process to take away land rights from the first inhabitants. Reynolds mentioned that the argument of wasted lands became very pertinent, especially to show evidence of Aboriginal resistance to European occupation (REYNOLDS, 1987, p. 65).

Indeed, Reynolds' inquiry of wasted lands could be applied to all European colonies. The Australian history is for much effect powerful evidence that could have been collected in any other colonized nation. Possibly, a lack of negotiation to acquire Indigenous land rights took place without a meeting of the minds, or better saying a mutual understanding and much less a fair offer or a just bargain for natives.

In Central and South America, the history of colonization was not different as monetary compensation for Indigenous Peoples is not recorded. There is no official document accounted for Portuguese or Spanish compensation for dispossession of land. In fact, the Indigenous Peoples's land dispossession in Central and South America were in the name of the God and then there is no compensation as someone having spiritual eternity (LAS CASAS, 1552, p. 57). Coincidentally, Reynolds's inquiry into Indigenous Peoples's status quo is universal - were those people really considered people?

\section{Australian Justice Lionel Murphy legacy: the right to ask}

In Australian jurisprudence, a prominent scholar and advocate for Indigenous Peoples's land rights was Justice Lionel Murphy, although his legacy is well regarded in Australian individual rights, coincidentally an Aboriginal plaintiff claiming his free speech right (AUSTRÁLIA, 1982) protected in the Australian legislation and much later in his life for his opinions in the High Court of Australia - as well as his dissenting opinions (HOCKING, 1997, p. 271). In this context, his legal thoughts for under-represented sectors of the society are noteworthy especially when he devoted legal thought to issues involving Aboriginal land rights. 
Murphy's role in freeing the legal mind from the blinkers of sole allegiance to English legal authority will be recognized by history. To him it was more than a matter of Australian self-respect. It was not just nationalism - for as his foray into the World Court demonstrated, Lionel Murphy was always an internationalist." [...] Although nothing that Lionel Murphy wrote specifically addressed the issue of land rights for Australia's indigenous peoples, it is hard for me to conceive of the possibility that the second Mabo decision or the Wik decision of the High Court could have occurred if the culture of the High Court had been the same as it was when Lionel Murphy arrived." See, also, for Aboriginal land rights, on page 317. "Indeed the intellectual underpinnings of Murphy's judgments have been clearly reflected in the more recent thinking of the High Court, particularly under Chief Justice Gerard Brennan (HOCKING, 1997, p. 317).

Justice Murphy's dissenting opinion on Coev. Commonwealth of Australia and another, High Court of Australia in 1978 is worthy to be mentioned. In that decision, although the claim was dismissed, Justice Murphy laid down the elements for dealing with issues of traditional custodians of the land through "occupation, settlement and continuing dealing in the lands" (AUSTRALIA, 1978, p. 412). Justice Murphy might have been not a popular scholar in the Privy Council seated in England, which has popularized the res nullius theory among colonies. But he opened the door to fresh jurisprudence and legal creativity to deal with such unfairness for Aborigines. In a sense, Justice Murphy forecasted what Justice Brennan defined in Mabo decision by establishing the innovative Australian common law in terms of occupation.

"Occupation" was originally a legal means of peaceably acquiring sovereignty over territory otherwise than by secession or conquest. It was a cardinal condition of a valid "occupation" that the territory should be terra nullius - a territory belonging to no one - at the time of the alleged act to constitute the occupation. "Territory inhabited by tribes or peoples having a social and political organization cannot be of the nature terra nullius". The extent to which the international law of occupation 
incorporated in Australia municipal law is a question which would arise for determination in the proceedings" ${ }^{1}$.

Clearly, the great contribution that Justice Lionel Murphy left for Australia as well as for international jurisprudence, particularly to the decolonized nations was that colonies were occupied by peoples with prior social and legal structure, which makes terra nullius a nullius theory. His mathematical rationale is applicable to any other Indigenous Peoples land rights claims, as well as territories where Indigenous Peoples still occupy. Therefore, the importance of Justice Murphy opinion in Coe v. Commonwealth (1978) transcended the domestic jurisdiction of Australia to possibly be entertained in other foreign courts, if the question of land rights claims arises in other decolonized countries² (AUSTRÁLIA, 1978, p. 138). Justice Murphy rationale that Aboriginal land rights remained untouched particularly when colonization ceased to exist is a powerful argument for any Indigenous Peoples' claims challenging terra nullius theory originally shaped by William Blackstone in 1765. It gives argument for future negotiation with decolonized nations, not to return to the status quo ante of dispossession as it would be illegal and unjust. It would be rather a good start to recognize that Indigenous Peoples were free in their own land and entitled to their land rights prior to colonization. The political tension was against the metropolis power and once that is gone, the nation left behind is free to legislate and to be creative in the legal solutions. To accommodate Indigenous Peoples claims in a decolonized State is a question of fairness as well as of maturity.

In Mabo and Others v. The State of Queensland in 1992 the claim of ownership was formally asked. The plaintiffs asked whether property existed prior to the English crown possession of the Torres Strait Islanders, which is part of mainland Australia. For that matter, past jurisprudence gave support to innovative reasoning in the highest court, particularly

1 See, Coe v. Commonwealth of Australia and Another [1979] heard in 1978, High Court of Australia HCA 68; 53 ALJR 403; (1979) 24 ALR 118 (5 April 1979) p. 412.

2 See, Mabo v. Queensland [n.2] (1992) 175 CLR 1 heard and delivered on June $3^{\text {rd }} 1992$, on respect to common law Native Title. 
from Justice Murphy, who gave a lead in the topic. In 1992, the High Court of Australia affirmed Aboriginal claims to their traditional land with more confidence than in 1978. Back there, it was not completely understood that Justice Murphy's dissenting position in Coe v. Commonwealth challenging the legality for Aboriginal sovereignty was reasonable to be claimed. Then, in Mabo the answer for this land claims test was that:

Like other legal rights, including rights of property, the rights conferred by common law native title and the first title itself can be dealt with, expropriated or extinguished by valid Commonwealth, State or Territorial legislation operating within the State or Territory in which the land in question is situated. To put the matter differently, the rights are not entrenched in the sense that they are, because of their nature, beyond the reach of legislative power. The ordinary rules of statutory interpretation require, however, that clear and unambiguous words be used before there will be imputed to the legislature any intent to expropriate or extinguish valuable rights relating to property without fair compensation. Thus, general waste lands or Crown lands legislation is not to be construed, in the absence of clear and unambiguous words, as intended to apply in a way which will extinguish or diminish rights under common law native title (AUSTRÁLIA, 1992).

Therefore, to assume that people are dispossessed of their rights because of their national origin or ethnic group is a form of racism (INTERNATIONAL..., 2009). Having Justice Murphy introduced the question for the first time in Coe offered receptiveness for Mabo decision in 1992 showing the maturity required for repairing social relations and justice.

\section{Selected theory for Aboriginal Peoples rights, the tale that becomes reality in the Australian society}

Unquestionably, as a result of the historical evidence collected by Reynolds, Indigenous Peoples in Australia were entitled to claim land rights in court. Moreover, The Racial Discrimination Act (1975), the 
dissenting opinion of Justice Murphy's decision at Coe v. Commonwealth (1978) allied to substantial findings from the book The Law of the Land ${ }^{3}$ (REYNOLDS, 1987, p. 205) Reynolds contributed to provoke a legal revolution in Australian land rights theory ${ }^{4}$ (REYNOLDS, 1987, p. 209). Following that, it was just expected that more discussion of Indigenous land rights would occur to fairly design Aboriginal rights legal mechanisms within Australian common law native title.

An outstanding contribution to the Australian land rights claims came from the multi-initiative discussion paper commissioned by the Aboriginal and Torres Strait Islander Commission focusing on Australian Indigenous Cultural and Intellectual Property entitled Our Culture: Our Future ${ }^{5}$ (JANKE, 1998). The relevant guidelines in this Report are dedicated to the protection of Indigenous Peoples' intangible rights and how to apply guidelines effectively for them locally. How does the native title to traditional land can secure intellectual property rights to Indigenous Peoples? Clearly, you are what your culture is. In fact, the cultural intangible rights may survive if Indigenous Peoples in Australia are committed to maintain their identity as people. For that they need a place to continue their cultural ancestry rituals, their agriculture

3 The question of Aboriginal and Islander land rights was a recurring theme of long discussions I had with the principal plaintiff, Eddie Mabo, during the late 1970s. While he spoke compellingly of his life as a boy on Murray Island and of his family's traditional land, I told him a little about Australian law - or as much as I knew of it at the time. I still vividly remember the occasion when a colleague and I explained to Eddie that, regardless of his customary rights, the whole of Murray Island was considered to be crown land and that, as Queensland's solicitor-general was later to tell the High Court, he and his fellow islanders were technically trespassers who could at any moment be legitimately driven off the island.

4 "On Wednesday 3 June 1992, the High Court of Australia delivered its judgment in the case of Mabo v. Queensland. It represented a legal revolution, one that was closely related to many of the themes dealt with in this book. The case and the book were related in other ways as well. [...] The High Court had brought Australian jurisprudence into line with Australian history".

5 Surry Hills, a report commissioned by Australian Institute of Aboriginal and Torres Strait Islander Studies and the Aboriginal and Torres Strait Islander Commission published in 1998 by Michael Frankel and Company Solicitors. It proposes recommendations based on around 70 submissions from organizations, individuals and other parties to the topic. 
lifestyle, their burial procedure, their oral tradition to others. Along these lines, the Report concluded that for intangible rights enjoyment for Indigenous Peoples in Australia, a modern definition of Aboriginal cultural and intellectual property must be created so that legal protection is defined for scientific, agricultural, technical, ecological research involving Traditional Knowledge. As a result of the Report and its guidelines, Indigenous Peoples would be protecting their cultural and environment resources efficiently ${ }^{6}$ (JANKE, 1998, p. 307-310). The Report did not spell for land rights entitlement, but rather supported self-determination and a sense of community in the traditional land.

As a result, Our Culture, Our Future (Janke) combined the positive results from legal theories, government, historical initiatives and interested Indigenous Peoples groups being an important document to define the object of legal protection of Indigenous Peoples' intangible and tangible rights. Also, it ratified that education and proper information process should be shared by Indigenous Peoples in Australia for their decision making process judging the best options for the community. Education and information increases their leverage in the bargain process for claiming their land rights ${ }^{7}$ (JANKE, 1998, p. 97).

6 For a synonymous of "Indigenous Cultural and Intellectual Property Rights", Janke used "Indigenous Heritage Rights" on which the modern definition includes: "Literacy, performing and artistic works (including music, dance, song ceremonies, symbols and designs, narratives and poetry, Languages, Scientific, agricultural, technical and ecological knowledge (including cultigens, medicines and sustainable use of flora and fauna), Spiritual knowledge, All items of moveable cultural property including burial artefacts, Indigenous ancestral remains, Indigenous human genetic material (including DNA and tissues), Cultural environment resources (including minerals and species)".

7 Janke reported that: "Indigenous people need to be informed about the range of laws which may impact on their Indigenous Cultural and Intellectual Property Rights including archives laws, land rights laws, native title, defamation, racial vilification, privacy law, trade practices laws, customs laws, administration and probate laws and broadcasting laws. Indigenous people need to be informed about how these laws may be of benefit to their needs in relation to the use and control of their Indigenous Cultural Heritage material. There is a need for greater consideration concerning how these range of laws might assist Indigenous peoples achieve their Indigenous Cultural and Intellectual Property Rights".

Revista de Direito Econômico e Socioambiental, Curitiba, v. 3, n. 1, p. 227-252, jan./jun. 2012 
In the absence of land rights or any sort of land entitlement that creates a stable status quo for Aboriginal Peoples, it is possible to misconceive what conservation of natural resources was meant to be in the CBD. Because of Indigenous Peoples' bond with local flora and fauna they have a different engagement with rich natural resources. It lacks economically driven exploitation of natural resources, but rather encompasses a relationship of respect. This is not the economic view advocated by economic forces like the mining industry, which is involved in exploiting rich natural resources areas that coincidentally are disputed in land rights claims by Aboriginal Peoples in Australia ${ }^{8}$.

At the international level, environmental resources sustainability is a question divided between material affluence and non-market amenities, which means management without complete depletion for "adequate transfer of assets from present to future generations" (HOWARTH; NORGAARD, 1995, p. 111-138). Although the adequate transfer of environmental assets is considered within the context of climate change that affects traditional land use and claims, it is clear that the sustainability of biological assets depends upon Aboriginal Peoples' survival in their local environment.

Similarly, a theory of "territorial knowledge" was proposed by then the Australian representative at the United Nations Conference on Trade and Development (DRAHOS, 2004). Drahos demonstrated a progressive interaction between national governments and Aboriginal Peoples for "retention of traditional biodiversity-related knowledge "associated with "access to the land" (DRAHOS, 2004, p. 25). Drahos's observations on Traditional Knowledge protection at international level involve tolerance for "diversity of traditional knowledge"; "reciprocity";

8 Western Australia is a typical region for legal challenges and disputed claimed area for Aboriginal Peoples' claims. It is the largest area claimed as Aboriginal People's traditional land. Coincidentally Western Australia is well known by his rich mineral resources in Kimberley region. That mining exploitation first developed in 1885, one of the richest deposits of gold, diamonds, petroleum, zinc and lead, iron ore, nickel, crude oil. See, also, the Kimberley Development Commission website available at: <http://www.kdc.wa.gov.au/invest/ik_econ_mine.asp>. Last seen 17 September, 2009.

Revista de Direito Econômico e Socioambiental, Curitiba, v. 3, n. 1, p. 227-252, jan./jun. 2012 
"national treatment", "mutual recognition" and "an international enforcement pyramid" (DRAHOS, 2004). His arguments are also construed to monitor progress amongst stakeholders, especially Aboriginal Peoples, businesses, mining industry, and the government in order to forge accountability among parties involved.

Drahos's argument for supporting land rights and cultural manifestations go further in suggesting a label and certification of origin for Indigenous Peoples's products. (DRAHOS, 2004) Therefore, products from Aboriginal land could be subject to certification if the traditional land entitlement to control and manage biological resources as well as land interest is subject to definition of property right in local legislation. Consequently, it will avoid falsehood in certifying Indigenous Peoples's products as an authentic cultural manifestation from a particular region in the planet.

\section{Conclusions}

The Convention on Biological Diversity, article 8 (j) foresees protection to natural resources associated with Traditional Knowledge from local communities, particularly, Indigenous Peoples's intangible rights. Ineffectiveness could be the latest outcome for signing and ratifying States to the Convention, if definition of land rights is not legally and jurisprudentially shaped by competent organisms in the local level. From all decolonized countries and democracies signing the Convention, Australia has evolved from total refusal of Indigenous Peoples' land rights to moral acceptance and further strong commitment to legal protection of Indigenous Peoples in Australia. In the Australian experience, history, jurisprudence, legislation and legal scholarship have recognized property for Aborigines on their traditional land. Whenever a dispute over natural resources involved the traditional land, there are public organisms capable of agreement or to further refer the judicial dispute to the highest court. Australia started with full support of terra nullius theory to 
absolute refusal after decolonization and further review of past policies for wasted lands.

Other countries with similar terra nullius historical background can be inspired by Australian historical and jurisprudence experience in order to design their own Indigenous Peoples's rights. In reviewing their own history, Australia rendered the Convention on Biological Diversity a strong international treaty with application to their internal matters involving land rights. Furthermore, the Convention on Biological Diversity also needs a national and local legal framework to work properly, so it is a synergy that should be forged from international to national and from national to international treaty. That is not to say that local administration is not crucial to make international law to be incorporated in the domestic environment. Again, Australian governments from the past could have hardly managed what the present administration has achieved. Then, good will and honesty is necessary. Also, the full effective mechanism for article $8(j)$ depends on prior land interests claims to be decided fairly and properly litigated in the court or, alternatively, after state and federal legislation has been enacted. Yet, legislation should be concerned to foresee a unique administrative organism to deal with Aboriginal land rights claims such as the National Native Title Tribunal model, which is capable of full enforcement of rights and obligations, an arbitration organism that oversees the whole process of land rights for all involved stakeholders.

Those legal instruments will vary and increase their effectiveness according to the balance for or against Aboriginal land rights. If the social structure still is supporting terra nullius theory, much debate and controversy will follow in any country as the Australian experience can illustrate. The test that courts should apply refer to the Aboriginal connection to their traditional land as well as the social tolerance for Indigenous Peoples's rights. If the rest of the society disrespects Aboriginal land rights claims opposing to any determination of their rights to occupy their traditional land, their Traditional Knowledge will cease to exist as proposed by the colonization policies. In respecting Indigenous Peoples's land rights, there exists a substantial possibility to efficiently manage 
biological resources associated with Indigenous People's knowledge insitu for generations to come without depletion. The Australian experience illustrates that one can bury past Aboriginal dispossession of the law of the land, if one wishes to.

The author wishes to acknowledge with a thank you note to Dr. Heline Sivini Ferreira, Dr. Patryck Ayala, Dr. José Rubens Morato Leite and The Australian Government Solicitor, John Waugh (publications and web editor) for their support and help to edit this article.

\section{References}

AUSTRALIA. High Court of Australia. Coe v. Commonwealth of Australia and other 1978 HCA 68. 1978. Available at: <http://www.haguejusticeportal. net/Docs/NLP/Australia/Coe_High_Court_17-08-1993.pdf >. Access on: 14 Nov. 2010.

AUSTRALIA. High Court of Australia. Mabo v. Queensland, n. 2, 1992. Available at: 〈http://www.concernedhistorians.org/content_files/file/le/130.pdf $\rangle$. Access on: 18 Sept. 2009.

\section{AUSTRALIAN GOVERNMENT. The Department of the Environment,}

Water, Heritage and Arts. Available at: <http://www.environment.gov>. Access on: 14 Nov. 2010.

AUSTRALIAN HUMAN RIGHTS. Native Title. 1993. Available at: <http://www. humanrights.gov.au/social_justice/native_title/index.html>. Access on: 14 Dec. 2010.

COMMONWEALTH CONSOLIDATED ACTS. Australia ACT 1986 - Sect 14. 1996. Available at: <http://www.austlii.edu.au/au/legis/cth/consol_act/aa19 86114/ s14.html . Access on: 18 Sept. 2009.

CONVENTION on Biological Diversity. Available at: <http://www.cbd.int/>. Access on: 18 Sept. 2009. 
CONVENTION ON BIOLOGICAL DIVERSITY. History of the convention. 1992. Available at: <http://www.cbd. int/history>. Access on: 17 Sept. 2009.

DRAHOS, P. Towards an international framework for the protection of traditional group knowledge and practice. Geneva: International Framework, 2004.

HOCKING, J. L. M. A political biography. United Kingdom: Cambridge University Press, 2000.

HOWARTH, R. B.; NORGAARD, R. B. Intergenerational choices under global environmental change. In: BROMLEY, D. W. (Ed.). Handbook of environmental economics. Cambridge, MA: Blackwell Publishers, 1995. p. 111-138.

HOWITT, R. Towards native title agreements: issues of negotiation or organization. Available at: <http://www.es.mq.edu.au/rhowitt/NEGOT.htm>. Access on: 18 Sept. 2009.

INTERNATIONAL Convention on the Elimination of All Forms of Racial Discrimination. Available at: 〈http://www2.ohchr.org/english/law/cerd.htm〉. Access on: 18 Sep. 2009.

JANKE, T.; FRANKEL, M. Our culture: our future, final report on Australian indigenous cultural and intellectual property. Available at: <http://frankellawyers. com.au/media/report/culture.pdf>. Access on: 29 Dec. 2012.

LANGTON, M. et al. Honour among nations? Treaties and agreements with Indigenous Peoples. Carlton: Melbourne University Press, 2004.

LAS CASAS, B. The devastation of the indies: a brief account. Baltimore; London: John Hopkins University Press, 1992.

PARRY, A.; JARVIS, S. Different visions, different ways: lessons and challenges from the native title negotiations in South Australia. In: NATIVE TITLE CONFEREnCE, 1., 2003, Alice Spengs. Proceedings... Alice Spengs: Native Title Conference, 2003. Available at: <http://www.es.mq.edu.au/rhowitt/DIF_0037. htm>. Access on: 29 Dec. 2012. 
REYNOLDS, H. The law of the land. Australia: Penguin Books, 2003.

SPEECHES by the Hon Sir Gerard Brenna. In: INTERNATIONAL APPELLATE JUdGes CONFERENCE, 1., 1995, Ottawa, Canada. Proceedings... Ottawa: International Appellate Judges Conference, 1995.

Received: 11/30/2009

Recebido: 30/11/2009

Approved: 07/12/2012

Aprovado: 12/07/2012 